InVisible Culture • Issue 31: Black Studies Now and the CounterCurrents of Hazel Carby

\title{
Being and Becoming: The Grammar of Black Theory
}

\section{Matthew Omelsky 1}

${ }^{1}$ University of Rochester

Published on: Nov 15, 2020

DOI: 10.47761/494a02f6.e0eb943e

License: Creative Commons Attribution 4.0 International License (CC-BY 4.0). 


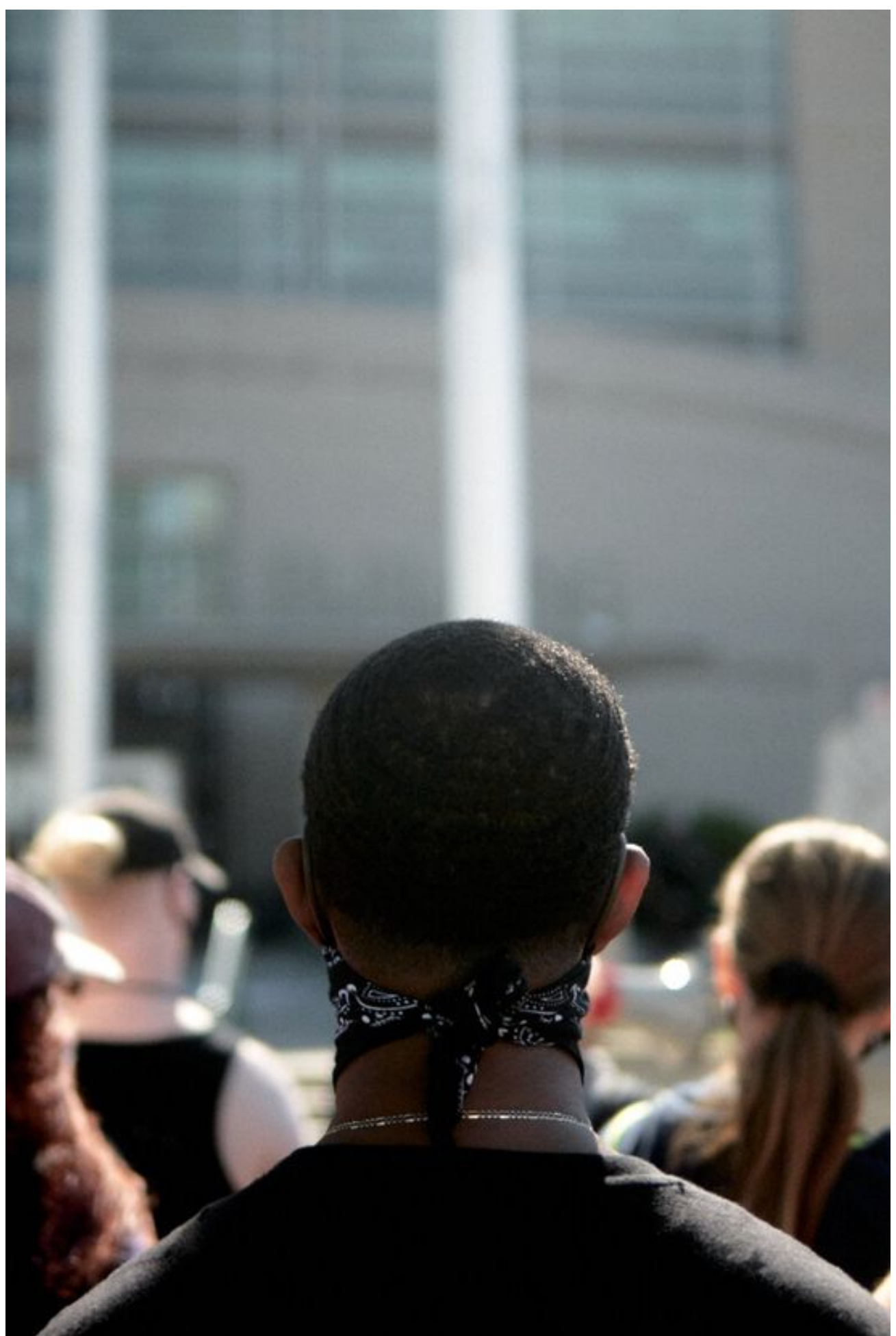

Featured Image: Protester at the Rochester Public Safety Building, June 2020. Photo by Martin Hawk, part of Pressure Gradient. 
There's a place in her 2009 essay, "Becoming Modern Racialized Subjects," when Hazel Carby's focus feels very much of our moment. Reading a series of early passages in The Interesting Narrative of the Life of Olaudah Equiano, Carby notes how, in the encounter with his European captors on the West African coast, a young Equiano is transformed into a kind of nothingness. In the moment of his racialization, she suggests, Equiano is rendered “cargo," he’s "dehumanized." “Terror and anguish follow Equiano's realization of the fragility, vulnerability and possible annihilation of the self, and movement, speech and consciousness cease, registering his symbolic death." 1 The entirety of Equiano's narrative is a kind of writing back to this moment of dehumanization, so that he might become something other than the abject, annihilated being he became in that inaugural encounter. He exudes, Carby goes on to say, a “constant urge to move beyond" the "body politics of modernity." $\underline{2}$

Carby's language and framing of this foundational representation of eighteenthcentury black subjection comes straight out of today's resurgent interest in questions of being and becoming in black studies theory. She refreshes our gaze into this iconic text, repositioning the weight of Equiano's autobiographical experience through the lens of today's theoretical vernacular. Her dwelling on Equiano's interpellation as nonbeing recalls the trenchant, pessimist-leaning work of David Marriott, Christina Sharpe, Calvin Warren, and others who galvanize a kind of vital energy by leaning into the historical nothingness of blackness. And her gesture to Equiano's desire to circumvent that nothingness, to escape the enclosure of that non-ontology, is reminiscent of the fugitive capacities of blackness explored by scholars like Tina Campt, Fred Moten, and Tavia Nyong'o. Carby's intellectual formation may be of a different historical moment-rooted more in the cultural, sociological, and critical ideological approaches of the Birmingham School-but her work, in one way or another, has for decades revolved around questions of being and becoming that these newer generation scholars have taken up in more explicitly theoretical terms. From her early work in Empire Strikes Back (1982) on the ideological construction of black school children as pathological in 1960s Britain, to her study in Cultures in Babylon (1999) of the stereotype-shattering black American women blues singers of the 1920s, to her recent unravelings of black British identity, Carby's extensive work has long contributed to questions of black historical being and subjectivity, and how (non)subjectivities are made and remade.

This special issue on Hazel Carby seems an apt occasion to take stock of today's theoretical discussions in black studies. The lens on this contemporary field that Carby's work demands, however, is not one confined just to the last few years, or, for 
that matter, to black American experience. What Carby has demonstrated over her career, is that the study of black life must be understood historically and transnationally. Her work calls on us to see beyond the apparent newness of contemporary theory, to revisit the critical antecedents that made today's interventions possible. And the sprawling internationalism of her work implicitly asks us to seek out the global threads of today's theory, and in turn, to refrain from equating American black studies with black studies writ large. This is central to Carby's reading of Equiano. In her focus on the life of the former slave who sailed around the world and experienced antiblack violence more than two centuries ago, she's foregrounding the transnational and historical sedimentations that have always constituted the archive of black study.

We need look no further than her latest book, Imperial Intimacies-Carby's magisterial excavation of black Britishness that threads personal and family memoir together with archival history-for a fuller sense of her expansive approach. Moving back and forth between Britain and Jamaica, capturing moments spanning nearly three hundred years, Carby shows how the being of (British) blackness has always been a kind of becoming, something in the making. And she gives us the tools to grasp a sense of the transnational and historical sprawl of that becomingness. Carby captures how her Jamaican father comported himself in particular ways in postwar Britain as a "counterweight" to "being treated as less than human." $\underline{3}$ She wonders if the dance costumes her Welsh mother sewed for her as a child were meant to serve as a kind of "armour" against violent racialized taunting. $\underline{4}$ She recalls how she had "longed for transformation" in those costumes, "becoming an ethereal floating being." $\underline{5}$ And Carby's deeper, historical ruminations are just as trenchant. Navigating the erasures of black life in eighteenth century Jamaican slave registers, she wonders how Lilly Carby - a former soldier in the British Army, thought to be the first Carby to come to the island-would have remembered the 1801 purchase of Nancy, her African ancestor: "Perhaps, when he looked at Nancy, or touched her, or beat her, or raped her, Lilly wanted to remember the first day he had gone shopping for flesh." $\underline{6}$ Imperial Intimacies shows us how the being and becoming of blackness so often blur into one another, and how that amalgamation, that convergence, changes shape as it traverses centuries, generations, races, and continents.

It's from this spirit of critical expansiveness, of seeing connections across disparate theories, histories, and geographies, that I want to speak to some of today's ideas in black theory. Rather than a comprehensive review, I want to point to a few ways we 
might grasp the vertical (historical) and horizontal (transnational) vectors of the work on black ontology and transformation that scholars are undertaking-vectors that Carby's work beckons us to see. My aim is to gesture to an expansive understanding of a set of discourses that often seem to emerge largely from contemporary black American experience, bottled up in the social and political alignments of US-based critical antagonisms. To be sure, many critics uphold the distinctions between the afropessimist and black optimist worldviews, standing by the putatively untraversable fault lines separating kindred (onto)logics. But so much of the generative work being done today, I contend, threads the needle, moving in and out and to the side of these contested categories in contemporary black theory. In what follows, I chart the ways certain critical terms and ideas have been passed down through generations of black studies scholars, often becoming reshaped and re-suited to fit new times, new politics, and indeed, new cultural geographies, circulating throughout global diasporic pathways in Africa and Europe, as well as the Americas. The thought of Fanon, Spillers, Wynter, and others has bubbled up to the surface of many of today's new voices, just as it has emerged in one way or another in studies of black life in places like Brazil, Germany, South Africa, and Kenya. The example of Hazel Carby's work, as I see it, compels an excavation of the present, a renewed look at the intellectual history and internationalism of the theory we produce today.

I want to begin with the percolation of ideas. The way thought seeps through generations of thinkers, how devised logics and conceptions of black subjection and desired freedom are passed down. Black studies theory as we know it today was initially built by scholars like W.E.B. Du Bois, Carter G. Woodson, Anna Julia Cooper, and C.L.R. James, whose pioneering historical and theoretical work in black feminism, anticolonialism, and the study of slavery in the Americas paved the way for the emergence of black studies as a formal academic discipline in the late-1960s and laid down a kind of foundational disciplinary grammar and knowledge. While much of this twentieth-century intellectual history can get lost in today's conceptual and performative innovations, one salient way to trace these histories is through keywords and their sedimented connotations. As a category, keywords, as Raymond Williams puts it, are "binding words." $\underline{7}$ They're the red threads that connect scholars and intellectual work, even if certain terms in the black studies context are shapeshifters, changing guise ever so slightly when picked up and extended by subsequent generations. Terms like double consciousness, intersectionality, social death, womanism, black radicalism, and diaspora are the grammar of black study, the 
building blocks of black knowledge production. As examples, I want to chart two particular terms that pervade today's theoretical work on being and becoming, to show how ideas drip across generations, how they change shape and redirect, how they create constellations of inter- and intra-generational connection.

The first is Frantz Fanon's concept of nonbeing. In Black Skin, White Masks (1952), Fanon describes what he understands to be the historical construction of blackness as pathological, as a thing in the world. He recalls his "tight smile" when a white child interpellated him as other: "Look, a negro!" "I took myself far off from my own presence, far indeed, and made myself an object. What else could it be but an amputation, an excision, a hemorrhage that spattered my whole body with black blood." $\underline{8}$ For Fanon, the European historical subjection of people of African descent signals a radical deracination of the body, of consciousness, of being-in-the-world. Blackness "bursts apart" in that moment of negation, forced to reconstitute itself as something other than being. As a result, blackness occupies a deceptive nothingness in the "zone of nonbeing," a space, he suggests, that is both "an extraordinarily sterile and arid region," but also "an utterly naked declivity where an authentic upheaval can be born." 9 For Fanon, writing at the precipice of the decolonization wave that would sweep across the African continent, nonbeing bears a doubled valence-manifesting at once as abjection and desire, nothingness and potentiality.

Fanon's work, and this concept in particular, saturates much of the theory in black studies today. While he was revered among radical thinkers and activists in his own time, his currency has exploded in our century, with scholars across a range of disciplines engaging with his work, producing a steady stream of monographs and special issues devoted to his anticolonial and antiracist thought. As for the concept of nonbeing, there are two overarching readings of it in our contemporary black studies moment. The one weighs more heavily on pessimism, looking to Fanon's descriptions of black amputated being, of nothingness, to speak to the historical experiences of black lives and bodies, in many cases focusing on the Americas. Frank Wilderson, for instance, cites Fanon to underscore the core afropessimist principle that blackness, for centuries, by means of both physical and epistemological violence, has been constructed as a fungible object, as an ontological void, as, in his words, "socially dead in relation to the rest of the world." 10 In Red, White \& Black (2010), he reads recent American cinema to demonstrate the construction of this non-ontology in relation to white and indigenous American positions. Taking a related though distinct approach is Christina Sharpe, whose In the Wake (2016) is concerned with what it means to live 
the aftermath of chattel slavery, in a contemporary world in which blackness remains inextricably bound up with death and disposability. Contending that black subjection is constitutive of democracy itself, Sharpe sifts through a capacious archive of poetry, photography, and film, seeking a form of "consciousness," new ways of inhabiting and imagining blackness's "insistence on existing."

The other predominant reading of Fanon's nonbeing emphasizes the second part of that zone: "an utterly naked declivity where an authentic upheaval can be born." In their respective fields of political, cultural, and literary theory, Neil Roberts, Darieck Scott, and Fred Moten attend more to the potential for transformation in Fanon's work on ontology. Moten, for instance, identifies a certain structure of fugitivity in Fanon's notion of the objecthood of blackness. "Some/thing escapes in or through the object's vestibule," he suggests in The Universal Machine (2018), "the object vibrates against its frame like a resonator and troubled air gets out." $\underline{12}$ For Moten, blackness as object resides in its own "appositional" space, to the side of other ontologies, enacting a kind of "regulatory disavowal," a social and celebratory energy of escape. And that infamous zone of nonbeing, for him, is the incubator of that disavowal, a "laboratory" that generates refusal. $\underline{13}$

The other keyword I briefly want to chart through some of these conversations in black theory is the flesh, as Hortense Spillers initially presents it in "Mama's Baby, Papa's Maybe: An American Grammar Book." In the essay's search for a kind of fundamental language through which to conceptualize black historical experiences of violence, she distinguishes between the flesh and the body, between the "captive and liberated subject-positions." 14 The flesh, she says, is the "zero degree of social conceptualization" of black trauma. It's the "primary narrative" of black historical wounding, the "seared, divided, ripped-apartness, riveted to the ship's hole," which historically "ungendered" the captive as a "commodity of exchange," as a quantity rather than a human being. $\underline{15}$ The wounded flesh forms a kind of veiled "hieroglyphics," a series of "undecipherable markings on the captive body," that, Spillers speculates, may very well be transferred from generation to generation, forming a sprawling intergenerational structure of trauma with a multitude of signs and symptoms. $\frac{16}{16}$ This fleshly marking also distinguishes what she calls the "vestibular" position of blackness in relation to dominant culture and the law. Which is to say, blackness as that which resides near to, but decidedly outside of, normative subjectivity and personhood. 
Similar to Fanon's nonbeing, this idea of the flesh threads throughout today's work. In Habeas Viscus (2014), Alexander Weheliye extends Spillers's flesh to become a dialectical structure akin to the zone of nonbeing. He surmises a kind of proleptic, or anticipatory, function of the flesh, reading it as simultaneously "a tool of dehumanization and a relational vestibule to alternate ways of being." 17 The wounded flesh, in other words, occupies the precarious (temporal and ontological) threshold separating annihilation from regeneration, the end of the world from a new order of the human. Taking up a different part of Spillers's formulation, C. Riley Snorton expands on the idea of historically ungendered captive flesh to construct a genealogy of black transness in Black on Both Sides (2017). "[If] the capacity for gender differentiation was lost in the outcome of the New World, ordered by the violent theft of body and land," Snorton suggests, "it would stand to reason that gender indefiniteness would become a critical modality of political and cultural maneuvering within figurations of blackness." 18 Before turning to an expansive, more contemporary archive, he reads instances of cross-gender modes of fugitive escape in nineteenth century slave narratives by Harriet Jacobs and William and Ellen Craft, examining how "chattel persons gave rise to an understanding of gender as mutable and as an amendable form of being." $\underline{19}$ In addition to Snorton and Weheliye, the flesh in recent years has figured prominently across a range of critical work, from Amber Musser's aesthetic study of black and brown sensualities, to Ashon Crawley's work on the sonic and social worlds of the black Pentecostal church, to Alexis Gumbs's critical-poetic excavation of black feminist theory. $\underline{20}$

Like Fanon's theories of ontology, Spillers's flesh and its critical progeny have created their own world, becoming one of those iconic signifiers in a distinctly black critical grammar that scholars continue to redirect and extend, contributing to a black theoretical apparatus that's always changing shape and always on the move. What's undeniable is that this newer generation of thinkers is pushing this apparatus in new directions, bringing a creative, performative energy to their thought and prose, shifting it to fit the emergent cultures, politics, and exigencies of our time. What's also indisputable, though perhaps less visible, is the way Hazel Carby's own work moves in and through these genealogies. 1987 saw the publication of Spillers's "Mama's Baby, Papa's Maybe," but also Carby's Reconstructing Womanhood, her now-foundational study of black women's writing in the US. $\underline{21}$ And her work as a mentor is also critical here: Saidiya Hartman-whose Scenes of Subjection, among other influential texts, continues to be an animating force both in pessimist- and optimist-leaning black studies work-was a student of Carby's in the early-1990s. $\underline{22}$ Carby was one of the 
early voices guiding "Performing Blackness," the dissertation project that would go on to become Hartman's groundbreaking Scenes.

A pivot is necessary here in this gestural map of black studies theory. To this point, many, though certainly not all, of the scholars I've mentioned are largely writing from an American national context, grounding their theorizations in histories of chattel slavery, mass incarceration, queer of color persecution, police brutality, and other issues that have marked the black American experience. In the Carbian spirit of thinking across national boundaries, as well as across historical paradigms of thought, I want to turn to the more explicitly global complement to this contemporary theorythat is, the theoretical work that overtly pushes us beyond narrowly American visions of black study.

That broader scope comprises scholars studying the contours of black life from Europe to South America, Africa to the Pacific. It involves searching for culturally and historically specific languages of black being and becoming, logics organic to other soils. In some cases, it means twisting and contorting contemporary American or European theory, or the ideas of foundational thinkers like Fanon, to the shape of disparate global experiences, resulting in novel formulations and politics. My provisional gesture to the sprawl of global black theory focuses on some of the comparative work spanning countries and continents, and some of the dynamic work happening on the African continent.

There are, unsurprisingly, a host of scholars in a variety of disciplines, like João Costa Vargas, Denise Ferreira da Silva, Tina Campt, and Vince Schleitwiler, committed to the study of racialized identities and violence in multiple points of the global diaspora. In their transnational juxtapositions, they search for underlying logics of subjection, histories that seep across borders, shared structures of colonial domination, and kindred desires for freedom in order to gain a larger, more encompassing sense of what produces black (non)being and becoming globally. Campt, in Image Matters (2012) and Listening to Images (2017), performs this search for common logics and desires in quotidian photographic archives. The former examines what she calls "vernacular" photographs-amateur, casual, and professional studio photos-of black German and black British families in the early twentieth century, attending to the ways images "stage intentions, aspirations, and performances of black European subjects in formation," how they "[enunciate] self and community, (af)filiation and improvisation." $\underline{23}$ Vargas's The Denial of Antiblackness (2018), in contrast, is a 
transnational afropessimist reading of contemporary politics of race in Brazil and the US. Drawing on a range of disciplines and approaches, including ethnographic studies conducted in Austin, Rio de Janeiro, and Los Angeles, Vargas charts a common structure of black dehumanization perpetuated through what he calls "oblique identification": the phenomenon wherein nonblacks engage in a kind of surface empathy toward black victimization, but nonetheless remain unwilling or unable "to grasp the underlying antiblack transhistorical logic that produces Black oppression and suffering." 24 Perhaps apt to this entire field of transnationally-focused work, Vargas insists that his is a relational project, not a comparative one: the notion that different African diasporic cultural geographies can be thought alongside one another because the world's animating logic, "informing cognition, sociality, and the management of life and death technologies, is antiblackness." $\underline{25}$

The shape of discussions around being and becoming in contemporary Africa are similarly diverse in their disciplines, though they come with salient distinctions. The continent, to be sure, has lived its own psychic and material devastations since the fifteenth century, as Walter Rodney chronicles in How Europe Underdeveloped Africa (1972) from the stratified societies that pre-date European contact to the slave trade to formal colonization. While today's Africans may not embody precisely the same "hieroglyphics of the flesh" as today's descendants of American slaves-meaning, that same residue of captivity and forced removal to another continent-they embody the sediments of their own historical subjections, their own kind of fleshly wounds, as it were, many of which relate, to varying degrees, to the afterlives lived by those in diaspora today. After all, it was largely the same European powers that controlled the Atlantic slave trade for hundreds of years and later colonized the vast majority of continent, extracting resources, conscripting labor by force, and removing groups from ancestral lands, paving the way for the postcolonial autocracies of the 20th and 21st centuries. If the histories of the continent and those in diaspora are simultaneously interconnected and distinct, it follows that contemporary African theory, at turns, moves through, alongside, and away from diasporic theory.

Questions of being and becoming in African theory in the last two decades revolve around various social and political concerns, much of it influenced by a range of intellectual traditions. On the Postcolony (2001) and "Necropolitics" (2003), among other works, have distinguished Achille Mbembe as arguably the continent's most prominent philosopher. With the latter essay, in particular, and the recent book of the same title-examining the contemporary use of technologies that create "deathworlds" in places like South Africa and Palestine-Mbembe is as close to an African 
afropessimist thinker as there is. $\underline{26}$ But there is also, I want to note, a cohort of emergent thinkers in African critical theory. Kenya-based scholar and blogger Keguro Macharia, for one, draws on a critical archive ranging from black feminism, to anticolonialism, to African philosophies, to poststructuralist thought to make sense of the logics of subjection he sees undergirding contemporary politics and culture across the global diaspora. In "Queer Disposability," for instance, he examines how a Kenyan politician's comparison of "homosexuals to dogs" creates a shared homophobia, a kind of violent and exclusionary solidarity, which in turn demarcates a certain disposability, "a figure, body, life, who/that can be used to lubricate socio-political... interactions." $\underline{27}$ I would also count among these emergent critical voices Zama Mthunzi, Wanelisa Xaba, and the many South African student activists, who, since 2015, have fought to dismantle the white supremacist underpinnings of their university campuses and curricula. Alongside mass demonstrations and calls to remove public statues of prominent colonial figures, there has been a search for a critical grammar among these \#Fallist scholar-activists, drawing on the work of Wilderson, Fanon, Steve Biko, Audre Lorde, and others both to make sense of the "dehumanization" of blackness in universities, and post-apartheid South Africa more broadly, but also to find pathways to a new kind of decolonization. $\underline{28}$

What these various African thinkers have in common with more explicitly comparative, or "relational," thinkers is that their work speaks far beyond just the continent. Mbembe and Macharia certainly have explicit global contours to their work, even if the continent is often their primary concern, but the South Africa-focused work of these student activists has also had significant global ramifications, inspiring allied protests and decolonial thought in Europe and North America. Rather than the well-worn narrative of Euro-America holding the exclusive theoretical and discursive power to shape ideas in the world, a new order of inter-animations has emerged where ideas are generated in the interstices of the global north and south. Indeed it's the dynamism of these transnational conversations, these antagonisms, these readings, reformulations, and novel inventions that may very well be the gravitational center of black studies theory in the years to come.

At the outset of her "Becoming Modern Racialized Subjects" essay, before she traces the formation of black Britishness from Equiano to the West Indian soldiers who served in the Second World War, Carby opens with a debt of gratitude to Stuart Hall, her former teacher and mentor. Amid her parsing of his legacy, she quotes one particular 
line from Hall, a kind of maxim for cultural analysis that's unexpectedly apt as I draw this essay to a close: "Theory," Hall explained, "is always a detour on the way to something more important." $\underline{29}$ Written decades into a career that shuttled back and forth between academia and public intellectualism, between theory and activism, these are words Hall knew well. That theorization is always provisional. That theory must necessarily lead to politics, lived experiences, greater insight. By extension, we might say, too, that theory is integral to making sense of the messiness of global relationalities, integral to seeing beyond well-worn parochialisms and national enclosures. Theory, in other words, is not the end game, but a tool for making sense of the world we know and the world we want to know. Indeed these are trenchant words at the end of a fleeting tour through theoretical material that leans into the heaviness of death and captivity, living and striving. They remind us that no matter who devised or revised a given term, no matter if that person lives in America or Kenya, no matter where an idea falls between pessimism and optimism, the foundation of this work is material lives, people who too often are still not treated as people. The discourse of being and becoming in twenty-first-century black theory enacts its own ecstatic energy, forging on in search of the fullness of a distinctly black theoretical grammar. It's performative, devastating, celebratory, exigent. But it's only a detour, Hall would insist, on the way to something else, something more important. As black studies theory continues to move toward that greater import, making room for it, excavating it, bringing it into being, that grammar must always speak to and run alongside the lived experiences of blackness in this world, even if that grammar dreams of worlds beyond this one.

\section{Footnotes}

1. Hazel V. Carby, "Becoming Modern Racialized Subjects," Cultural Studies 23, no. 4 (2009): 632-33.

2. Carby, “"Becoming Modern Racialized Subjects,” 634.

3. Hazel V. Carby, Imperial Intimacies: A Tale of Two Islands (London: Verso, 2019), 47.

4. Carby, Imperial Intimacies, 105.

5. Carby, Imperial Intimacies, 103.

6. Carby, Imperial Intimacies, 283. 
7. Raymond Williams, Keywords: A Vocabulary of Culture and Society (New York: Oxford University Press, 1983), 15. $\_$

8. Frantz Fanon, Black Skin, White Masks, trans. Charles Markmann (New York: Grove Press, 1967), 112.

9. Fanon, Black Skin, White Masks, 8. $\bullet$

10. Frank Wilderson, Red, White \& Black: Cinema and the Structure of US Antagonisms (Durham: Duke University Press, 2010), 18.

11. Christina Sharpe, In the Wake: On Blackness and Being (Durham: Duke University Press, 2016), 11.

12. Fred Moten, The Universal Machine (Durham: Duke University Press, 2018), 145. $\subseteq$

13. Moten, The Universal Machine, 224.

14. Hortense Spillers, “Mama’s Baby, Papa's Maybe: An American Grammar Book," Diacritics 17, no. 2 (1987): 67.

15. Spillers, "Mama’s Baby," 67.

16. Spillers, "Mama's Baby," 67. $\doteq$

17. Alexander Weheliye, Habeas Viscus: Racializing Assemblages, Biopolitics, and Black Feminist Theories of the Human (Durham: Duke University Press, 2014), 44. 18. C. Riley Snorton, Black on Both Sides: A Racial History of Trans Identity (Minneapolis: University of Minnesota Press, 2017), 56. $\Perp$ 19. Snorton, Black on Both Sides, $57 . \Perp$ 20. Amber Musser, Sensual Excess: Queer Femininity and Brown Jouissance (New York: New York University Press, 2018); Ashon Crawley, Blackpentecostal Breath: The Aesthetics of Possibility (New York: Fordham University Press, 2016); Alexis Gumbs, Spill: Scenes of Black Feminist Fugitivity (Durham: Duke University Press: 2016).

21. Hazel V. Carby, Reconstructing Womanhood: The Emergence of the AfroAmerican Woman Novelist (New York: Oxford University Press, 1989). 
22. Saidiya V. Hartman, Scenes of Subjection: Terror, Slavery, and Self-Making in Nineteenth-Century America (Oxford: Oxford University Press, 1997).

23. Tina Campt, Image Matters: Archive, Photography, and the African Diaspora in Europe (Durham: Duke University Press, 2012), 7-8.

24. João Costa Vargas, The Denial of Antiblackness: Multiracial Redemption and Black Suffering (Minneapolis: University of Minnesota Press, 2018), 5, 11.

25. Vargas, The Denial of Antiblackness, 6.

26. Achille Mbembe, “Necropolitics," Public Culture 15, no. 1 (2003): 40.

27. Keguro Macharia, "Queer Disposability,” Gukira, 8 March

2013, https://gukira.wordpress.com/2013/03/08/queer-disposabilityL; see also Keguro Macharia, Frottage: Frictions of Intimacy Across the Black Diaspora (New York: New York University Press, 2019).

28. See, for instance, Wanelisa Xaba, "Challenging Fanon: A Black radical feminist perspective on violence and the Fees Must Fall movement," Agenda 31, nos. 3-4 (2017): 96-104; Zama Mthunzi, "Afro-pessimism is the greatest form of Black optimism," The Daily Vox, 20 February 2017, https://www.thedailyvox.co.za/afropessimism-greatest-form-black-optimism-zama-mthunzi/..

29. Carby, “Becoming Modern Racialized Subjects,” 626. 